\title{
A potential solution for food security in Kenya: implications of the Quzhou model in China
}

\author{
Xiaoqiang JIAO, Jianbo SHEN, Fusuo ZHANG (凶) \\ National Academy of Agriculture Green Development, Department of Plant Nutrition, College of Resources and Environmental Science, \\ China Agricultural University, Beijing 100193, China
}

\begin{abstract}
Poor soil fertility due to low nutrient inputs is a major factor limiting grain production in Kenya. Increasing soil fertility for crop productivity in China has implications for food security in Kenya. The purpose of this study was therefore to investigate the historical patterns of grain production, nutrient inputs, soil fertility and policies in Quzhou, a typical agricultural county on the North China Plain, and to compare grain production in Quzhou County and Kenya to identify a potential approach for increasing grain production in Kenya. Grain yields in Quzhou increased from 1 to $3 \mathrm{t} \cdot \mathrm{ha}^{-1}$ between 1961 and 1987 by increasing manure application accompanied by small amounts of chemical fertilizer after soil desalinization. There was a further increase from 3 to $5 \mathrm{t} \cdot \mathrm{ha}^{-1}$ up to 1996 which can be mainly attributed to chemical fertilizer use and policy support. Hence, a beneficial cycle between soil fertility and plant growth in Quzhou grain production was developed and strengthened. In contrast, there was only a slight increase in grain yields in Kenya over this period, resulting from low soil fertility with limited external nutrient inputs, a consequence of poor socioeconomic development. It is suggested that grain yields in Kenya would likely be boosted by the development of a selfreinforcing cycling between soil fertility and plant growth with manure and chemical fertilizer use if supported by policy and socioeconomic development.
\end{abstract}

Keywords China, grain production, Kenya, soil fertility

\section{Introduction}

Rapid global socioeconomic development over the past 50 years has driven an unprecedented increase in food crop productivity ${ }^{[1]}$. For example, cereal production, mainly wheat, rice and maize, has tripled during this period with

Received June 8, 2020; accepted August 25, 2020

Correspondence: zhangfs@cau.edu.cn only a $30 \%$ increase in the cultivated land area but with corresponding population growth ${ }^{[2]}$. The number of malnourished people has decreased dramatically during this period, even though the population has doubled to 5.8 billion $^{[3,4]}$. In addition, the curse of Malthusian famine has been broken. However, some developing countries still struggle with food security issues, especially in subSaharan Africa ${ }^{[5,6]}$. According to statistical analysis, 169 million Africans, particularly children, were undernourished annually during the $2000 \mathrm{~s}^{[7]}$. Thus, issues related to food security in Africa need to be addressed urgently.

China has fed its large population successfully during the past 50 years ${ }^{[8]}$. Grain yields in China increased from $1 \mathrm{t} \cdot \mathrm{ha}^{-1}$ in the $1960 \mathrm{~s}$ to more than $5 \mathrm{t} \cdot \mathrm{ha}^{-1}$ in the $2000 \mathrm{~s}$, with an increase in grain per capita from less than $200 \mathrm{~kg}$ to more than $400 \mathrm{~kg}^{[8]}$. There are a number of factors contributing to this impressive achievement, including mineral fertilizer use, policies, and socioeconomic development ${ }^{[9]}$. There has been an increase in chemical fertilizer usage from 1 to $53 \mathrm{Mt}$ since the 1960s which can largely explain the increase in Chinese grain production ${ }^{[10]}$. In contrast, grain yields have remained stable at around at $1 \mathrm{t} \cdot \mathrm{ha}^{-1}$ with few mineral fertilizer inputs to crop production over the past 50 years in Kenya ${ }^{[11]}$. Furthermore, the amount of food produced in Kenya and also food imported from other parts of the world are insufficient to meet consumer demand and nutritional requirements ${ }^{[12,13]}$. The history of Chinese agriculture development over the past 50 years may provide important experience and lessons learned to help increase grain yields in Kenya.

Soil productivity is the capacity of soils to store and supply water and nutrients to create an environment favorable for plant growth and function ${ }^{[14]}$. Initial success to build on agriculture development was achieved by increasing soil productivity ${ }^{[15]}$ and tripling crop yields in tropical Africa with replenishment of soil fertility ${ }^{[11]}$. Numerous studies demonstrate that if soil productivity is increased, food production in Africa can rise in a relatively short period of time ${ }^{[16]}$. The characteristics of cropping 
systems in China and Kenya were quite similar in the 1960s. Grain yields were quite low (around $1 \mathrm{t} \cdot \mathrm{ha}^{-1}$ ) and soil fertility was very low due to limited nutrient inputs. Soil fertility can be increased by the recycling of internal materials. For example, in theory, soil fertility can be restored by fallow with natural vegetation left to regrow for a number of years after cultivation ${ }^{[17]}$. However, in most cases, grain and straw have been removed without returning any nutrients to agricultural soils. This has led to soil nutrient depletion in the major Kenyan croplands over the long-term ${ }^{[18]}$. In fact, soil nutrient depletion has led to insufficient nutrients for crops and declining crop and straw production. Overall, soil nutrient depletion is the main source of low crop productivity in Kenya.

Unlike Kenya, China has designated the soil fertility of agricultural land a top priority with strong policy support in the development strategy defined by the Chinese government, with particular emphasis on the importance of increased soil fertility using external nutrient inputs such as chemical fertilizers and organic manures ${ }^{[9]}$. Use of organic and inorganic fertilizers is a key factor in the increase in soil fertility in China to break the cycle of low productivity ${ }^{[19]}$. Chemical fertilizers were considered to be a silver bullet to boost crop yields in China in the $1980 \mathrm{~s}^{[9]}$. Extension of the knowledge of external nutrient inputs such as chemical fertilizers and manures for increasing soil fertility and grain yields is essential for the transfer of the successful Chinese grain production experience to grain yields in Kenya. Numerous studies have highlighted the importance of Chinese experience and the challenges faced by Kenyan agriculture ${ }^{[20,21]}$ to build soil fertility from the technology perspective in countries, but the importance of the socio-economic context has not been fully understood.

Quzhou is a typical agricultural county located in Hebei Province on the North China Plain, a region responsible for about $38 \%$ of Chinese grain production and with an area similar to that of Kenya. Approximately $90 \%$ of the population in Quzhou County is engaged in agricultural activities. The average land area allocated to a farm is about 0.6 ha and this is divided into two to six separate fields. The agricultural area is dominated by small farms. The major crop rotation system in Quzhou is winter wheat (Triticum aestivum) followed by summer maize (Zea mays). Quzhou County and Kenya have much in common in terms of grain production. Almost $70 \%$ of the population in Kenya is involved in agriculture. The arable land area per person is less than 1 ha. Smallholders are a central pillar in Kenyan rural development ${ }^{[22]}$. Low soil fertility was the major factor limiting grain production in the 1960s. Similar to Quzhou County, grain yields in Kenya were low in the $1960 \mathrm{~s}$, less than $1 \mathrm{t} \cdot \mathrm{ha}^{-1}$. However, this increased to $3 \mathrm{t} \cdot \mathrm{ha}^{-1}$ in the $1980 \mathrm{~s}$, reached $5 \mathrm{t} \cdot \mathrm{ha}^{-1}$ in the 1990s, and exceeded $5 \mathrm{t} \cdot \mathrm{ha}^{-1}$ in the 2000s in Quzhou ${ }^{[23]}$. However, grain yields have remained at about $1 \mathrm{t} \cdot \mathrm{ha}^{-1}$ due to low nutrient inputs over the past 50 years in Kenya.
Comparison of the dynamic trajectory of grain production in Quzhou County and Kenya reveals the importance of manipulating soil fertility using technology and socialeconomic conditions to increase grain production.

Therefore, initially a database of grain production, resource inputs, soil fertility status and relevant policy and socioeconomic indicators in Quzhou County and Kenya was interrogated. Comparison was then made of the dynamic trajectories of grain production in the two areas by investigating the factors contributing to grain yield increase at different stages in Quzhou. Finally, the implications of the dynamic trajectories of grain production at Quzhou County to increasing agricultural productivity in Kenya were analyzed.

\section{Materials and methods}

Data on Kenyan and Quzhou cereal grain yields were obtained from the Chukwuka (2017) and Quzhou yearbooks for 1961-2016 ${ }^{[24,25]}$. Grain yield represents the average yields of maize, wheat, barley (Hordeum vulgare), buckwheat (Fagopyrum esculentum), millet (Pennisetum glaucum), rye (Secale cereale), sorghum (Sorghum bicolor) and triticale (Tritico secale). Data on chemical fertilizer inputs per unit of arable land were calculated as the ratio of chemical fertilizer consumption and the area of arable land and permanent crops, obtained from the sources mentioned above. Data on soil salt, organic matter, total $\mathrm{N}$ and available $\mathrm{P}$ contents at Quzhou County and Kenya were compiled from published and unpublished data sources between 1961 and 2015. Likewise, all samples were collected from surface soil $(0-20 \mathrm{~cm}$ depth) before sowing.

In addition, large collections of soil test data and soil surveys conducted by the Quzhou Government in 1978, 1980, 1999, 2002 and 2010 were used to evaluate the variability of soil fertility from 1960 to 2015 . Data on soil fertility met the following criteria: (1) soil organic matter content was determined by wet digestion with $\mathrm{H}_{2} \mathrm{SO}_{4}$ $\mathrm{K}_{2} \mathrm{Cr}_{2} \mathrm{O}_{7}$ and then converted to soil organic matter content with a factor of $1.724^{[26]},(2)$ soil total $\mathrm{N}$ concentration was determined by the Kjeldahl method with thiosulfate modification to include $\mathrm{NO}_{3}-\mathrm{N}^{[27]}$, and (3) soil available $\mathrm{P}$ concentration was determined using the vanadomolybdate method $^{[28]}$.

Nutrient balances, such as $\mathrm{N}$ and $\mathrm{P}$, for different grain yield levels of major croplands in Quzhou County and Kenya were calculated using the method of Potter et al., based on the data from the FAO and Quzhou yearbooks ${ }^{[24,25,29]}$. Nutrient inputs included fertilizers, manures and deposition, and output was crop removal. Data on chemical fertilizers were obtained from the International Fertilizer Association (2017) and Quzhou yearbooks 1961-2015. Nutrient removal and manure were calculated by Potter's method in 2008, which is also based on data 
from $\mathrm{FAO}^{[24,25,29]}$.

The nutrient balance function was calculated as:

$$
\text { Nutrient balance }=\mathrm{N}_{\text {manure }}+\mathrm{N}_{\text {fertilizer }}-\mathrm{N}_{\text {removal }}
$$

where $\mathrm{N}_{\text {manure }}$ is $\mathrm{N}$ and $\mathrm{P}$ from manure, $\mathrm{N}_{\text {fertilizer }}$ is $\mathrm{N}$ and $\mathrm{P}$ from chemical fertilizer, and $\mathrm{N}_{\text {removal }}$ is $\mathrm{N}$ and $\mathrm{P}$ removed in crops.

Crop $\mathrm{C}$ includes carbon from crop residues $\left(\mathrm{C}_{\text {crop residual }}\right)$, root biomass and rhizodeposition $\left(\mathrm{C}_{\mathrm{R}}\right)$ was calculated by the method of Johnson et al. ${ }^{[30]}$ :

$$
\mathrm{C}_{\text {crop }}=\mathrm{C}_{\text {crop residual }}+\mathrm{C}_{\mathrm{R}}
$$

where crop residual $C\left(C_{\text {crop residual }}\right)$, root biomass and $C_{R}$ are defined by the following equations:

$$
\mathrm{C}_{\text {crop residual }}=\frac{\mathrm{Y}_{\text {crop }}}{\mathrm{HI}} \times k
$$

where $\mathrm{Y}_{\text {crop }}$ is average grain yield, $\mathrm{HI}$ is harvest index of crops, and $k$ is the concentration in crop residues,

$$
\mathrm{C}_{\mathrm{R}}=\left(\mathrm{C}_{\mathrm{Y}}+\mathrm{C}_{\mathrm{V}}\right) \times k
$$

where $\mathrm{C}_{\mathrm{Y}}$ is average crop yield, $\mathrm{C}_{\mathrm{V}}$ is crop residue, $k$ is a constant of 0.50 for wheat and 0.33 for maize ${ }^{[30]}$.

\section{Results}

3.1 Dynamic trajectories of grain per capita and grain yield in Quzhou County and Kenya

Grain per capita in Quzhou County and Kenya showed significant different dynamic trajectories from 1961 to 2014 (Fig. 1(a)). Grain per capita increased rapidly from less than $100 \mathrm{~kg}$ per capita in 1961 to $505 \mathrm{~kg}$ per capita in 1987 and reached a maximum of $868 \mathrm{~kg}$ per capita in 1996 , with $891 \mathrm{~kg}$ per capita at Quzhou in 2014. However, it did

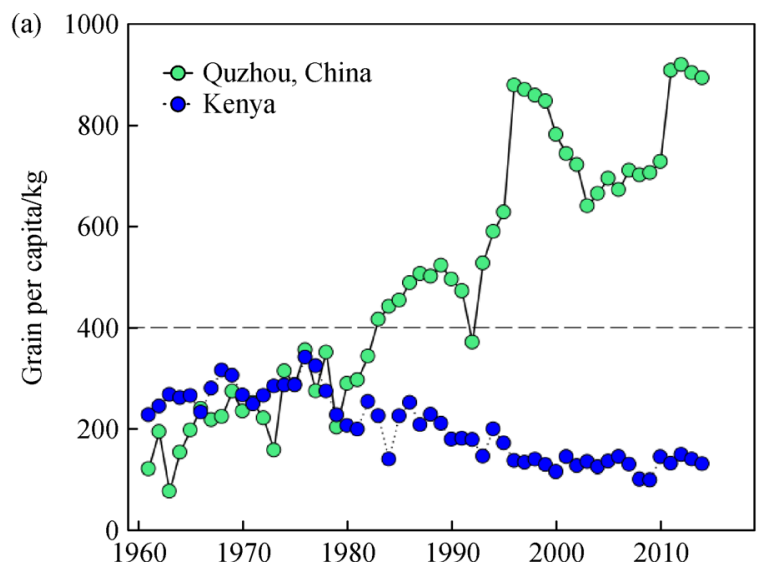

not increase uniformly over the past 50 years, but instead showed some fluctuations. From 1961 to 1998 the increase was steady, declined sharply from 1999 to 2002, and then linearly over the last decade (2003-2014). However, in Kenya, grain per capita increased slowly from 1961 to 1968 and then declined linearly until 2014.

Considerably different patterns of increase in grain yield were observed in Quzhou County and Kenya over the 50 years (Fig. 1(b)). Indeed, grain yields in Quzhou increased 20 times from $0.4 \mathrm{t} \cdot \mathrm{ha}^{-1}$ in 1961 to $7.8 \mathrm{t} \cdot \mathrm{ha}^{-1}$ in 2014. Grain yield increased to $3.0 \mathrm{t} \cdot \mathrm{ha}^{-1}$ in the $1980 \mathrm{~s}$ and reached $5.0 \mathrm{t} \cdot \mathrm{ha}^{-1}$ in the $1990 \mathrm{~s}$. Grain yield in Quzhou was more than $5.0 \mathrm{t} \cdot \mathrm{ha}^{-1}$ in the $2000 \mathrm{~s}$. The net increase in grain yield from 1961 to 2014 was $7.4 \mathrm{t} \cdot \mathrm{ha}^{-1}$ with an annual rate of increase of $3.7 \%$. In contrast, grain yield in Kenya has showed only a slight increase, largely remaining around about $1 \mathrm{t} \cdot \mathrm{ha}^{-1}$ from 1961 to 2014 .

3.2 Nutrient input and balance in arable land at Quzhou County and Kenya

The amount of $\mathrm{N}$ input to arable land at Quzhou County and Kenya was considerably different (Fig. 2). In Kenya, total $\mathrm{N}$ input was about $12 \mathrm{~kg} \cdot \mathrm{ha}^{-1}$ including less than $10 \mathrm{~kg} \cdot \mathrm{ha}^{-1}$ as chemical $\mathrm{N}$ inputs. There was no noticeable difference between grain yields of the two areas until the mid-1990s (less than $2 \mathrm{t} \cdot \mathrm{ha}^{-1}$ ). However, Quzhou doubled the total $\mathrm{N}$ inputs at $25.4 \mathrm{~kg} \cdot \mathrm{ha}^{-1}$, with chemical $\mathrm{N}$ inputsn of $21.5 \mathrm{~kg} \cdot \mathrm{ha}^{-1}$. In addition, grain yield increased from 3 to $5 \mathrm{t} \cdot \mathrm{ha}^{-1}$ with the combination of an eight-times increase in $\mathrm{N}$ input, $216 \mathrm{~kg} \cdot \mathrm{ha}^{-1} \mathrm{~N}$ in total including $206 \mathrm{~kg} \cdot \mathrm{ha}^{-1}$ chemical $\mathrm{N}$ input. As grain yield increased to more than $5 \mathrm{t} \cdot \mathrm{ha}^{-1}$, with further corresponding rising $\mathrm{N}$ inputs of about $378 \mathrm{~kg} \cdot \mathrm{ha}^{-1} \mathrm{~N}$ to the arable land, including $355 \mathrm{~kg} \cdot \mathrm{ha}^{-1}$ chemical $\mathrm{N}$ fertilizer (Fig. 2(a)).

Similar trends in both $\mathrm{N}$ and $\mathrm{P}$ inputs to arable land were observed at Quzhou County and Kenya (Fig.2(c)). In

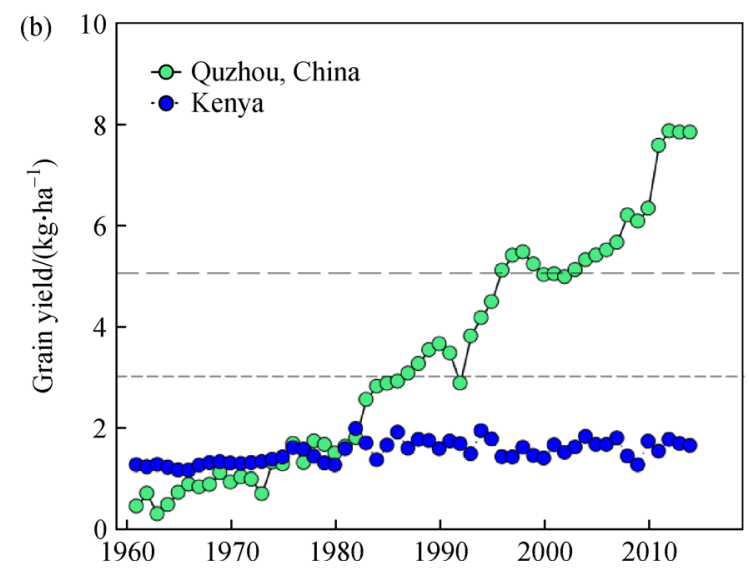

Fig. 1 Grain per capita (a) and cereal grain yield (b) in Quzhou, China and Kenya from 1961 to 2014. Grain yield represents average yield of maize (Zea mays), wheat (Triticum aestivum), barley (Hordeum vulgare), buckwheat (Fagopyrum esculentum), millet (Pennisetum glaucum), rye (Secale cereale), sorghum (Sorghum bicolor), and triticale (Tritico secale). Data from FAOSTAT database $(\mathrm{FAO}, 2017)^{[2]}$ and Quzhou yearbooks of 1961-2015 $5^{[25]}$. The two dashed lines in grain yield (b) indicate 3 and $5 \mathrm{t} \cdot \mathrm{ha}^{-1}$. 

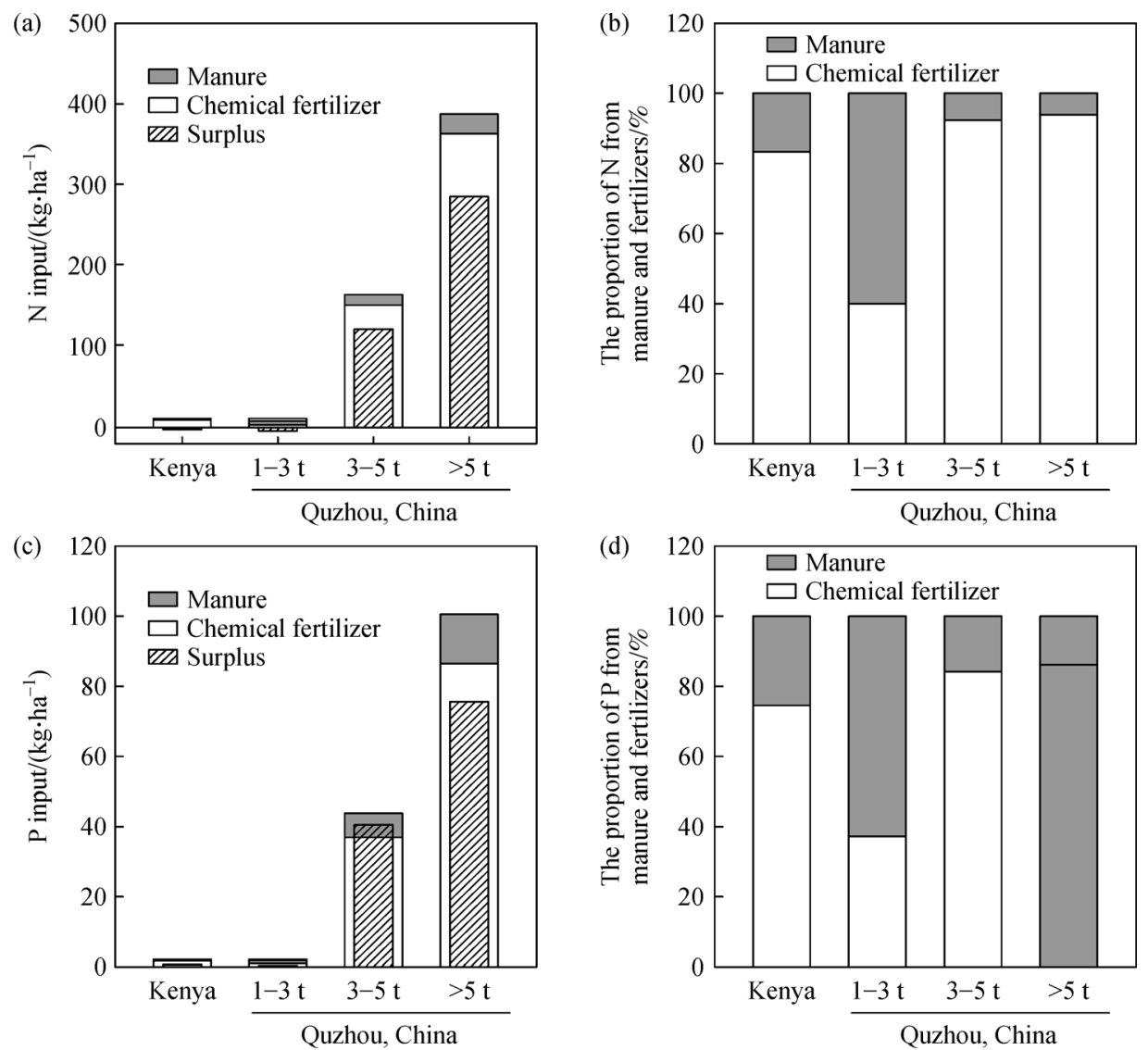

Fig. 2 Nutrient input and surplus (a, for N; c, for P) and the proportion of nutrient (b, for N; d, for P) from manure and fertilizers in Kenya and different yield levels in Quzhou, China from 1961 to 2014. 1-3 t, 3-5 t, $>5$ represent the grain yield level per unit area at Quzhou. The time periods for 1-3 t, 3-5 t, > 5 t yields are before 1987, 1987-1996, and after 1997, respectively.

Kenya, the total $\mathrm{P}$ input was about $2 \mathrm{~kg} \cdot \mathrm{ha}^{-1} \mathrm{P}$ throughout this period. At Quzhou, total $\mathrm{P}$ input increased from $5.8 \mathrm{~kg} \cdot \mathrm{ha}^{-1}$ in the $1-3 \mathrm{t} \cdot \mathrm{ha}^{-1}$ grain yield period to $59 \mathrm{~kg} \cdot \mathrm{ha}^{-1}$ in the $3-5 \mathrm{t} \cdot \mathrm{ha}^{-1}$ grain yield period. Chemical $\mathrm{P}$ fertilizer was the dominant input, with a ten-times increase, with a total $\mathrm{P}$ input of $92 \mathrm{~kg} \cdot \mathrm{ha}^{-1}$ to the arable land.

The proportion of $\mathrm{N}$ and $\mathrm{P}$ from chemical fertilizer increased with yield in Quzhou (Fig. 2(b,d)). About $40 \%$ of $\mathrm{N}$ and $\mathrm{P}$ was derived from chemical fertilizer when grain yield in Quzhou was 1-3 t $\cdot \mathrm{ha}^{-1}$. The percentage increased to more than $90 \%$ when grain yield was above $5 \mathrm{t} \cdot \mathrm{ha}^{-1}$.

In Kenya, soil $\mathrm{N}$ and $\mathrm{P}$ depletion has been common in arable land over the past 50 years (Fig. 2(a,c)). The average $\mathrm{N}$ and $\mathrm{P}$ depletion each year was about $4 \mathrm{~kg} \cdot \mathrm{ha}^{-1}$ in arable land in Kenya. At Quzhou, $\mathrm{N}$ was depleted by $4 \mathrm{~kg} \cdot \mathrm{ha}^{-1} \mathrm{~N}$ in the $1-3 \mathrm{t} \cdot \mathrm{ha}^{-1}$ grain yield period with little $\mathrm{P}$ accumulation in the soil. As grain yield increased from 3 to $5 \mathrm{t} \cdot \mathrm{ha}^{-1}, 122 \mathrm{~kg} \cdot \mathrm{ha}^{-1} \mathrm{~N}$ and $41 \mathrm{~kg} \cdot \mathrm{ha}^{-1} \mathrm{P}$ accumulated in Quzhou soils. A similar pattern was seen as grain yield increased with $286 \mathrm{~kg} \cdot \mathrm{ha}^{-1} \mathrm{~N}$ and $76 \mathrm{~kg} \cdot \mathrm{ha}^{-1} \mathrm{P}$ surpluses were observed in more than the $5 \mathrm{t} \cdot \mathrm{ha}^{-1}$ grain yield period at Quzhou.
3.3 Soil fertility in the topsoils of Quzhou County and Kenya

In general, soil fertility was lower in Kenya than Quzhou County (Fig. 3), particularly available soil P compared with soil organic matter and soil total N. Available P was only $5 \mathrm{mg} \cdot \mathrm{kg}^{-1}$ in Kenyan croplands over the past 50 years (Fig. 3). In contrast, in Quzhou croplands, soil organic matter increased from 8 to $12 \mathrm{~g} \cdot \mathrm{kg}^{-1}$ from the $1-3$ to $3-5 \mathrm{t} \cdot \mathrm{ha}^{-1}$ crop yield period. With more than $5 \mathrm{t} \cdot \mathrm{ha}^{-1}$ grain yield, available $\mathrm{P}$ reached $15 \mathrm{~g} \cdot \mathrm{kg}^{-1}$ (Fig. 3(c)). The soil total $\mathrm{N}$ doubled as grain yield increased (Fig. 3(b)). In addition, available $\mathrm{P}$ in the topsoil was only $5 \mathrm{mg} \cdot \mathrm{kg}^{-1}$ when grain yield was $1-3 \mathrm{t} \cdot \mathrm{ha}^{-1}$, and increased to more than $20 \mathrm{mg} \cdot \mathrm{kg}^{-1}$ when the grain yield was $3-5 \mathrm{t} \cdot \mathrm{ha}^{-1}$ and more than $5 \mathrm{t} \cdot \mathrm{ha}^{-1}$ (Fig. 3(c)).

\subsection{Crop C return to the soil}

In Kenya, crop C (carbon from crop residues, root biomass and rhizodeposition) returned to the soil has been low over the past 50 years, only $0.15 \mathrm{~kg} \cdot \mathrm{ha}^{-1} \mathrm{C}$ annually (Fig. 4). However, there was an increase in crop residual $\mathrm{C}$ at 

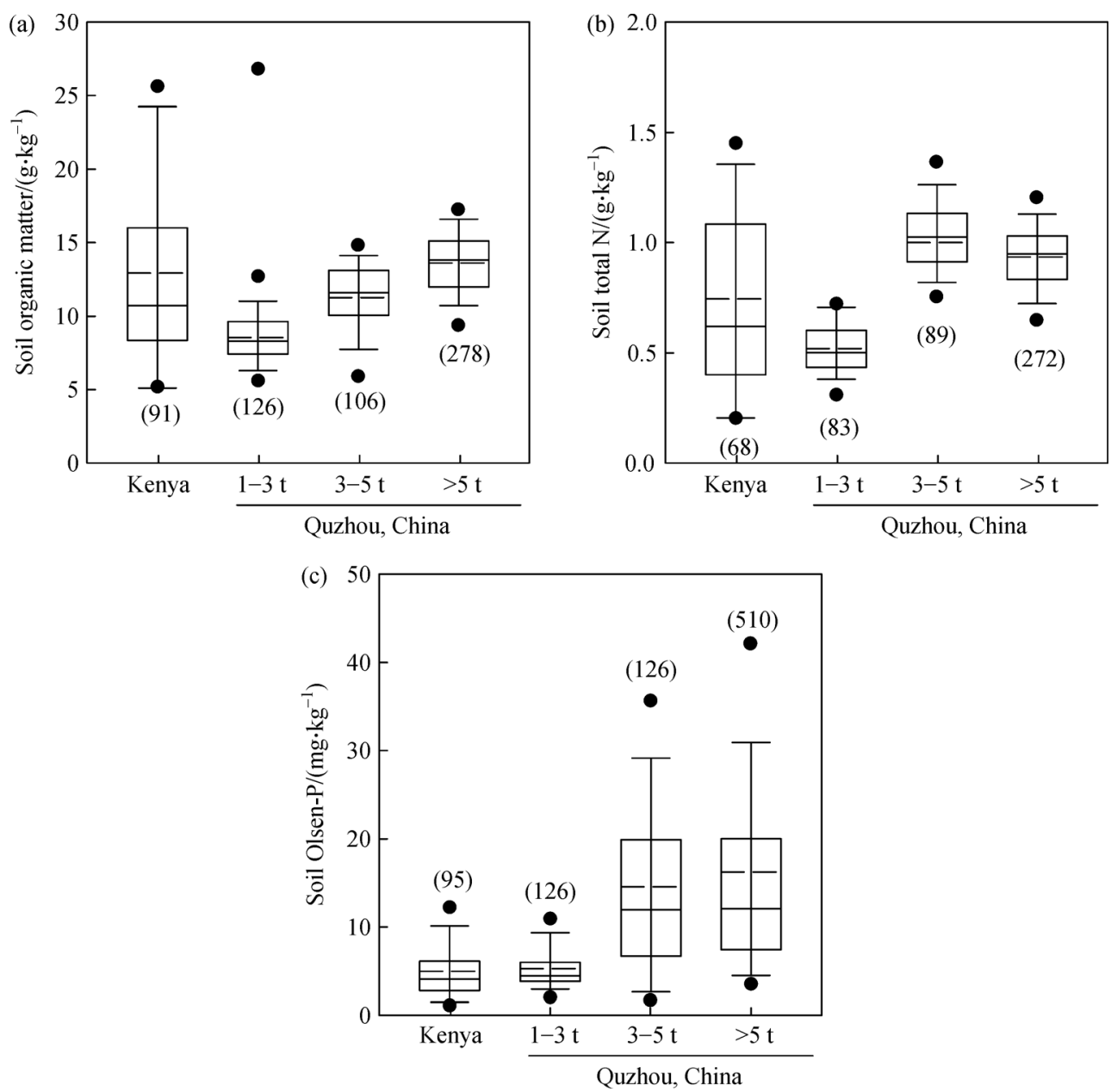

Fig. 3 Soil organic matter (a), soil total N (b), and soil Olsen-P concentration (c) of the topsoil in Kenya and different yield levels in Quzhou, China from 1961 to 2014. Data from soil survey conducted by Quzhou, China and Kenya governments, published papers and unpublished data sources. The number in brackets is the number of soil samples. 1-3 t, 3-5 t, $>5 \mathrm{t}$ represent the grain yield level per unit area in Quzhou. The time period for 1-3 t, 3-5 t, > 5 t yields were before 1987, 1987-1996, and after 1997, respectively.

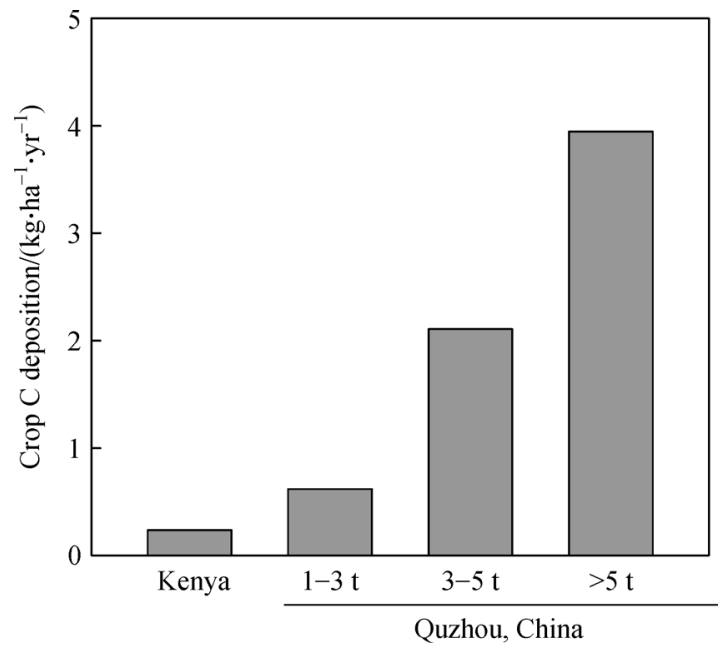

Fig. 4 Crop C deposition, which includes crop residual C, root biomass and rhizodeposition C, in the major Quzhou, China and Kenyan croplands in different periods. The methods of calculating crop residual C, root biomass and rhizodeposition C are from Johnson et al. ${ }^{[30]}$. 1-3 t, $3-5 \mathrm{t},>5 \mathrm{t}$ represent the grain yields per unit area in Quzhou. The time period for $1-3 \mathrm{t}, 3-5 \mathrm{t},>5 \mathrm{t}$ yields are before 1987, 1987-1996, and after 1997, respectively. 
Quzhou which increased according to grain yield. When the grain yield was $1-3 \mathrm{t} \cdot \mathrm{ha}^{-1}$, crop residual $\mathrm{C}$ was $0.33 \mathrm{~kg} \cdot \mathrm{ha}^{-1} \mathrm{C}$. It increased three times when grain yield was $3-5 \mathrm{t} \cdot \mathrm{ha}^{-1}$ and reached $1.45 \mathrm{~kg} \cdot \mathrm{ha}^{-1} \mathrm{C}$ with more than $5 \mathrm{t} \cdot \mathrm{ha}^{-1}$ grain yield.

\subsection{Evolution of grain and fertilizer policy in Quzhou} County and Kenya

A series of policies were introduced by the Chinese government to increase grain yields (Fig. 5). From 1961 to 1978, all land was managed in communal systems and used according to state policy. In 1978, the household responsibility system was implemented which contracted land out to farmers and mobilized farmer enthusiasm for farming. In 1985, the grain bag project was started by the national Government, including subsidies for chemical fertilizers and raising the state procurement price for grain. From 1996, the price of chemical fertilizer was driven by market forces and the government gave many subsidies for chemical fertilizers. Hence, farmers in China could afford large amounts of chemical fertilizers. In 2003, the Chinese Government ceased taxing farming and began to provide farmers with huge amounts of subsidies.

\subsection{Relationship between GDP per capita and grain production and $\mathrm{N}$ surplus}

Over the past 50 years, grain yields at Quzhou have increased with GDP per capita (Fig. 6(a)). In contrast to grain yield above $5 \mathrm{t} \cdot \mathrm{ha}^{-1}$, the magnitude of yield increase with GDP per capita was larger when grain yield was below $5 \mathrm{t} \cdot \mathrm{ha}^{-1}$. The relationship between GDP per capita with grain yield in Kenya was similar to when grain yield was $1-3 \mathrm{t} \cdot \mathrm{ha}^{-1}$ at Quzhou.

$\mathrm{N}$ surplus increased with GDP per capita when GDP was 2000 USD and leveled off between 2000 and 4000 USD per capita, then declined after 4000 USD per capita. In Kenya, the relationship between GDP per capita and N surplus was similar to when grain yield was $1-3 \mathrm{t} \cdot \mathrm{ha}^{-1}$ at Quzhou (Fig.6(b)).

\section{Discussion}

4.1 Development of a self-reinforcing cycle between soil fertility and plant growth with increases in grain yield of $1-5 \mathrm{t} \cdot \mathrm{ha}^{-1}$

The contrasting changes in historical trajectories of grain per capita and grain yield at Quzhou County and Kenya over the past 50 years indicate that it is vital for grain production to build up soil fertility with manures and small amounts of chemical fertilizers, underpinning a potential approach to increase grain yields in Kenya through boosting soil fertility by developing a self-reinforcing cycle between soil fertility and plant growth (Fig. 1). At Quzhou, soil fertility has been increased by additional nutrient supply such as chemical fertilizers and manures for the stimulation of plant growth. At the same time, return of the crop carbon from crop residues, root biomass and rhizodeposition of boosted crops can further increase soil fertility. Consequently, this can create a self-reinforcing cycle between soil fertility and plant growth which has been very successfully developed in Quzhou grain production. This may explain the grain yield increases from 1 to $5 \mathrm{t} \cdot \mathrm{ha}^{-1}$ at Quzhou (Fig. 1). Similar results were obtained from differences in grain yields between fields

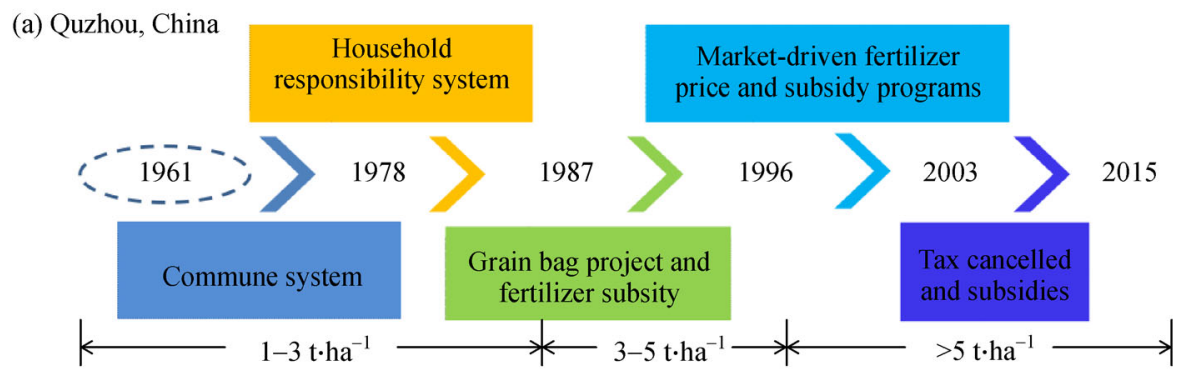

(b) Kenya

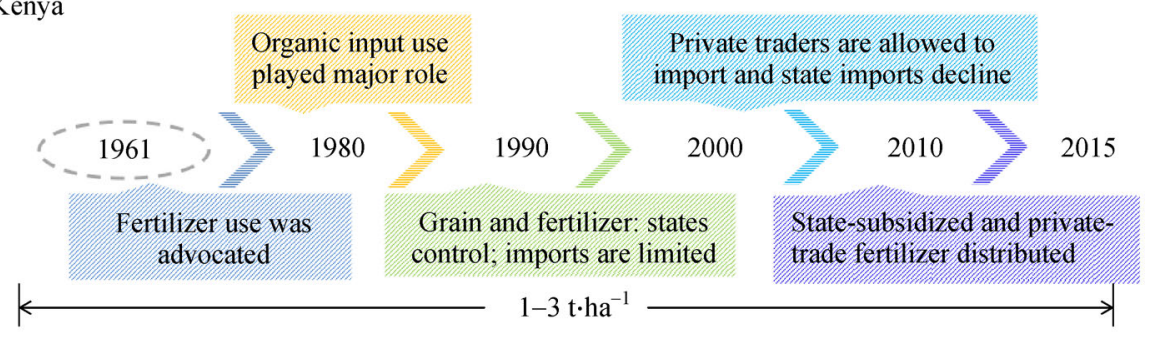

Fig. 5 Evolution of grain and fertilizer policies in Quzhou, China (a) and Kenya (b) during different periods. 

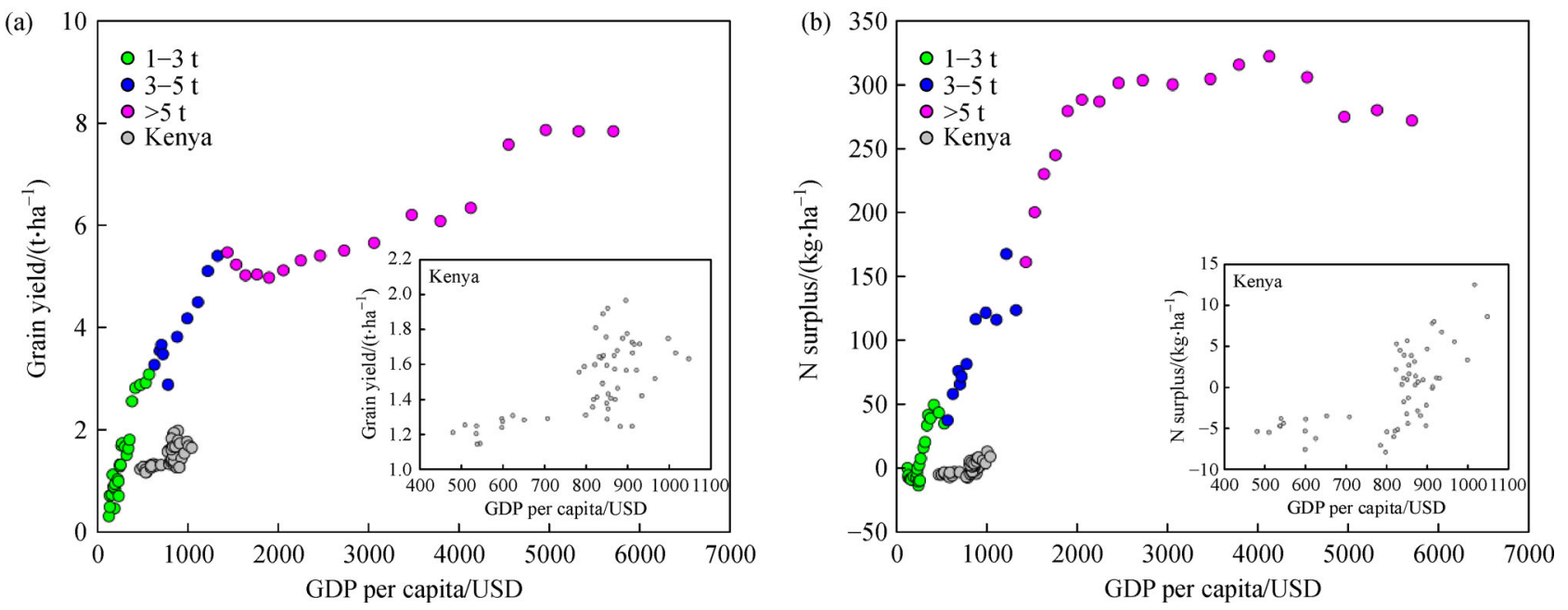

Fig. 6 Relationship between GDP per capita with grain yield (a) and N surplus (b) in the major Quzhou, China and Kenyan croplands in different periods. 1-3 t, 3-5 t, > $t$ represent the grain yield level per unit area at Quzhou. The time periods for $1-3 \mathrm{t}, 3-5 \mathrm{t},>5 \mathrm{t}$ yields are 1961-1987, 1987-1996, and 1997-2015, respectively.

near and distant from homesteads in Kenya ${ }^{[31]}$.

High soil salt concentrations were the major factor limiting crop growth in the major Quzhou arable areas in the 1960s and 1970s before a self-reinforcing cycle was established (Fig. S1). Reducting soil salt concentrations was critical. In general, the optimum soil salt concentration is $<1 \mathrm{~g} \cdot \mathrm{kg}^{-1}$ but was up to $4 \mathrm{~g} \cdot \mathrm{kg}^{-1}$ in the 1970 s. Large amounts of salt were removed from the surface soils and grain yields increased (Fig. S1).

Soil productivity is the capacity of the soil to maintain a supply of water and nutrients to create a favorable environment for all plant growth and functions. Indeed, the maintenance of soil fertility is a vital step in sustaining soil productivity, especially in resource-poor situations ${ }^{[9]}$. Agriculture development usually starts with high soil fertility ${ }^{[15]}$. For instance, crop yields in China increased by $2.8 \mathrm{t} \cdot \mathrm{ha}^{-1}$ in the $2000 \mathrm{~s}$ due to inreased soil fertility compared to the $1980 \mathrm{~s}$. Without increased soil fertility the increases in Chinese crop yields would have been impossible ${ }^{[32]}$.

Many agronomic practices have been advocated to increase the fertility of Chinese arable soils ${ }^{[9]}$. External nutrient inputs such as manures and chemical fertilizers were quickly adopted by Chinese farmers to increase soil fertility in the $1960 \mathrm{~s}$ and $1970 \mathrm{~s}^{[9]}$. Maintenance of soil fertility using manures is beneficial to crop production. It is widely believed that traditional Chinese farmers relied on organic manures to maintain long-term soil fertility ${ }^{[9]}$. Manures (containing crop residues and animal and human wastes) continued to be an important nutrient resource for crop growth before the introduction of chemical fertilizers (Fig. 2). In addition, manures improve soil structure, stimulate the availability of soil nutrients and microbial activity and carbon sequestration ${ }^{[33]}$. Here, soil organic matter increased from 8 to $12 \mathrm{~g} \cdot \mathrm{kg}^{-1}$ with manure use in arable land at Quzhou and grain yield increased from 1 to $3 \mathrm{t} \cdot \mathrm{ha}^{-1}$ (Fig. 3).

The role of chemical fertilizers in increasing soil fertility for high grain yields is beyond doubt. Grain production in many countries is promoted by chemical fertilizers, for example the European Union, the United States, and east Asia $^{[34,35]}$. A doubling of global grain production was associated with about a 7-fold increase in fertilizer $\mathrm{N}$ rates and 3.5 times fertilizer $P$ application from 1960 to $1995^{[36]}$. Around half the world population survives on food production that has benefitted from the invention of the Haber-Bosch process for nitrogen production ${ }^{[37]}$. Here, grain yield increased from 1 to $5 \mathrm{t} \cdot \mathrm{ha}^{-1}$ when chemical fertilizer $\mathrm{N}$ use increased from 20 to $180 \mathrm{~kg} \cdot \mathrm{ha}^{-1}$. Soil total $\mathrm{N}$ and Olsen-P contents increased significantly due to the use of chemical fertilizers (Fig. 3).

A beneficial cycle between soil fertility and plant growth for grain yield increase developed with manure and small amounts of chemical fertilizer use when the grain yield was $1-3 \mathrm{t} \cdot \mathrm{ha}^{-1}$. Grain yield increase from $<1 \mathrm{t} \cdot \mathrm{ha}^{-1}$ in 1961 to $3 \mathrm{t} \cdot \mathrm{ha}^{-1}$ in 1987 at Quzhou was underpinned by the use of manures and chemical fertilizers. The combined application of manures and chemical fertilizers provided nutrients to crops and also increased the nutrient status of the soils $^{[32]}$. Also, $\mathrm{N}$ and $\mathrm{P}$ accumulated in of Quzhou soils from the 1980s and reached surpluses of $150 \mathrm{~kg} \cdot \mathrm{ha}^{-1} \mathrm{~N}$ and $60 \mathrm{~kg} \cdot \mathrm{ha}^{-1} \mathrm{P}$ in the 1990s (Fig. 2). The increased inputs of crop residues, root exudates, root biomass and manures into arable areas can increase the soil organic matter concentration in the topsoil (Fig. 4). A beneficial cycle in the cropping systems of plant growth and soil fertility developed over this period (Fig. 7). The application of manures and fertilizers enhanced crop growth by building up soil fertility, and more carbohydrates from crop residues, root biomass and rhio-deposition due to boosted 


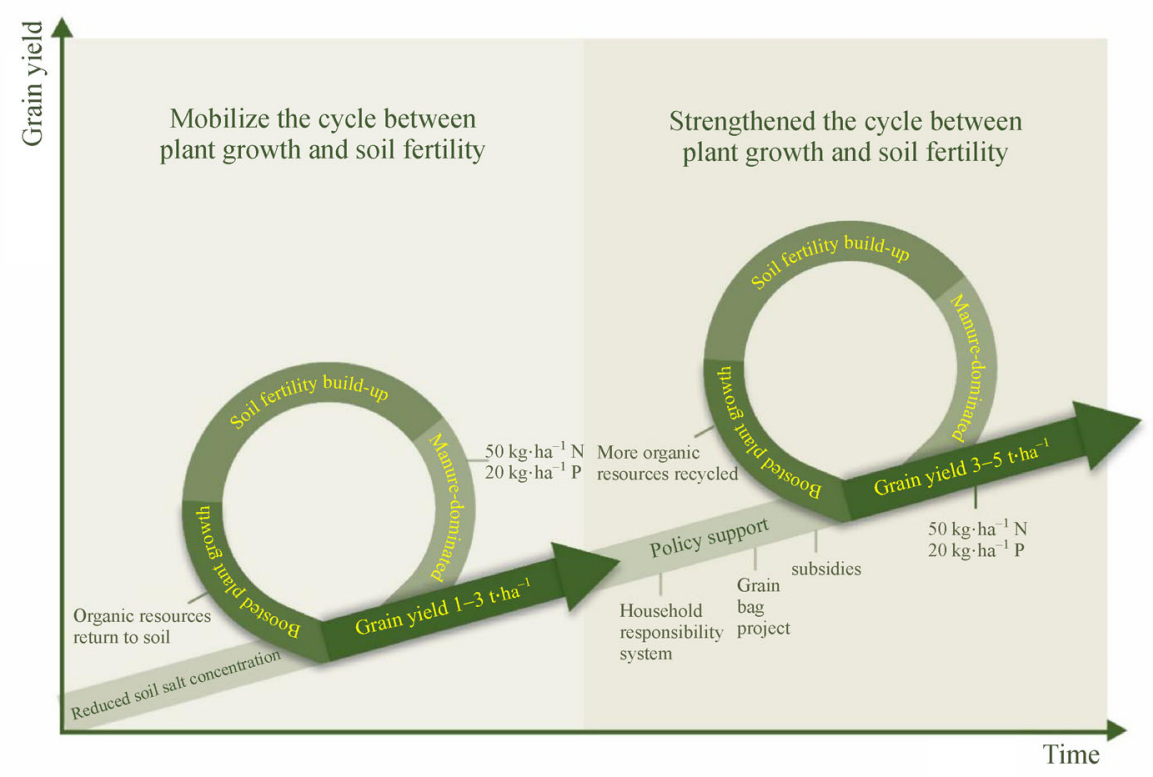

Fig. 7 Conceptual model of a self-reinforcing feedback between soil fertility and plant growth driven by nutrient inputs at Quzhou, that is, the implications for Kenya of soil fertility buildup in grain production in China.

crop growth contributed to soil fertility increase ${ }^{[30,38,39]}$ (Fig. 4).

In addition, here, a threefold increase (from $100 \mathrm{~kg} \cdot \mathrm{ha}^{-1}$ in 1988 to $300 \mathrm{~kg} \cdot \mathrm{ha}^{-1}$ in 1997) in chemical fertilizer rates explains the increase in grain yield from $3 \mathrm{t} \cdot \mathrm{ha}^{-1}$ in 1987 to $5 \mathrm{t} \cdot \mathrm{ha}^{-1}$ in 1997 (Fig. 2). Plentiful grain production was achieved by strengthening the beneficial cycle of plant growth and soil fertility with chemical fertilizer use. Policy and socioeconomic factors had a great impact on chemical fertilizer use during this period. For instance, the household responsibility system replaced the communal system in 1978 and permitted the contracting of land to famers and stimulated enthusiasm for farming. In 1985 the grain bag project was initiated with increased subsidies for cereal production, such as raising the state procurement price for cereals, subsidies for chemical fertilizers and other mechanisms. Economic development was rapid and GDP per capita increased linearly with grain yield and nutrient surplus at Quzhou (Fig. 6). All these factors contributed to grain yield increase based on the beneficial cycle of plant growth and soil fertility formed during the $1-3 \mathrm{t} \cdot \mathrm{ha}^{-1}$ grain yield period.

In contrast to grain production at Quzhou County, grain yields in Kenya have not increased significantly, with grain per capita, without considering non-grain crops (such as beans and cassava), of $<150 \mathrm{~kg}$, and many people in Kenya have been living under starvation over the past 50 years (Fig. 1). This was associated with soil nutrient depletion due to low manure and chemical fertilizer use for a long period. Major emphasis was placed on the use of chemical fertilizers to meet crop demand for nutrients and increase yields in Kenya in the 1960s and 1970s (Fig. 5).
However, due to shortfalls in infrastructure and high per unit cost of delivery, agricultural profitability was greatly reduced $^{[40]}$. For example, the farm-gate price of urea in western Kenya was $400 \mathrm{USD} \cdot \mathrm{t}^{-1}$ compared to $90 \mathrm{USD} \cdot \mathrm{t}^{-1}$ in Europe ${ }^{[41]}$. Therefore, only small amounts of fertilizer are used in Kenyan farming while European farmers have used $>200 \mathrm{~kg} \cdot \mathrm{ha}^{-1} \mathrm{~N}$ annually ${ }^{[12]}$. In addition, the plummeting food price is associated with underdeveloped regional transport systems, lack of storage facilities and extremely low earnings for the investment in increasing grain production ${ }^{[42]}$. Therefore, grain production could not be triggered due to depleted soil fertility in Kenya, although there are many policies for grain production and nutrient management in Kenya (Fig. 5). This was also related to socioeconomic development in Kenya (Fig. 6). Similarly, a fertilizer subsidy policy implemented in Malawi was unsuccessful due to soil nutrient depletion ${ }^{[43]}$.

The use of organic resources to maintain low soil fertility was advocated in the 1980s and 1990s in Kenya (Fig. 5). The application of organic resources undoubtedly enhanced crop yields in many regions of Africa ${ }^{[44]}$. However, low access to organic resources can likely explain the low yields in the 1980s and 1990s. Organic matter production often requires livestock, excessive land and labor. For example, in livestock systems in West Africa only $2.5 \mathrm{~kg} \cdot \mathrm{ha}^{-1} \mathrm{~N}$ and $0.6 \mathrm{~kg} \cdot \mathrm{ha}^{-1} \mathrm{P}$ were applied to arable land due to poor access to organic matter ${ }^{[18]}$. The use of organic resources such as manures and composts is part of an internal flow of nutrient within farms ${ }^{[18]}$. Furthermore, uncontrolled removal of natural vegetation over a long period has a negative impact on soil fertility in Africa $^{[45]}$. This practice has resulted in $22 \mathrm{~kg} \cdot \mathrm{ha}^{-1} \mathrm{~N}$ and 
$2.5 \mathrm{~kg} \cdot \mathrm{ha}^{-1} \mathrm{P}$ depletion annually over the past 30 years in 37 African countries. This annual nutrient loss costs the equivalent of 4 billion USD in fertilizers ${ }^{[41,42]}$. Long-term nutrient depletion resulted in soil degradation due to the self-reinforcing feedback between low soil fertility and plant growth ${ }^{[17,40]}$. Degraded soils cannot be rehabilitated with only manure application without chemical fertilizer use $^{[46]}$. Thus, it is vital to stimulate soil rehabilitation through the restoration of biomass productivity and $\mathrm{C}$ inputs to the soil using both chemical fertilizers and manures $^{[46]}$.

In addition to the limited availability of organic resources, there are many other challenges in adapting and adopting organic matter to build up soil fertility ${ }^{[18,47]}$. There are many competing uses of organic resources such as straw burning, animal feeds and composting ${ }^{[48]}$. Here, $\mathrm{N}$ and $\mathrm{P}$ derived from manure amounted to $<10 \mathrm{~kg} \cdot \mathrm{ha}^{-1}$ (Fig. 2). The composition of organic resources often does not match the nutrients required by crops ${ }^{[17,48]}$. Further, organic resources have undergone a decomposition phase and their $\mathrm{N}$ is usually less available than fresh inorganic resources of a similar biochemical analysis ${ }^{[4]}$. All factors cannot effectively drive the cycling of elements involving high crop production. Building up soil fertility by the combined use of manures and chemical fertilizers is therefore urgently required.

In low input and yield cropping systems, $1 \mathrm{t} \cdot \mathrm{ha}^{-1}$ grain yield can be obtained by recycling the internal materials. Soil fertility can be restored through fallow allowing natural vegetation to regrow for a number of years after cultivation $^{[17]}$. However, in most cases, grain yield and straw are removed without any return to the land, resulting in soil nutrient depletion in the major Kenyan croplands over long periods ${ }^{[18]}$. Depleted soils cannot provide enough nutrients to meet crop demand. Therefore, there are reduced amounts of crop and straw production. In addition, there is not enough arable land to be fallowed for soil nutrient restoration in Kenya with the increasing population and associated demands for land. The strategy toward growing biomass scarcity has led to a vicious cycle of low crop production in Kenya ${ }^{[49]}$ (Fig. 6(a)).

Low soil fertility from minimal use of manures and chemical fertilizers over long periods has led to grain yields in Kenya of $<2 \mathrm{t} \cdot \mathrm{ha}^{-1}$ (Fig. 1). In our study, external nutrient addition was one of the vital drivers to increase all nutrient elements for high crop production. Theoretically, in Kenya it is feasible to achieve a tripling in grain yield from $<2 \mathrm{t} \cdot \mathrm{ha}^{-1}$ by increasing the nutrient supply to the level currently used at Quzhou ${ }^{[11,50]}$. Compared with nutrient inputs, the adoption rate of genetically improved crops is similar in Asia and Africa. However, only a $28 \%$ increase in grain yield has occurred in Africa, due to the depletion of soil nutrients, and a 70\% increase has been achieved in $\mathrm{Asia}^{[41]}$. In most areas of Africa such as Kenya, the depletion rate of soil nutrients has been greater than replenishment with crop losses due to pests, diseases and abiotic stress ${ }^{[51]}$. A previous study shows that in Kenyan farming decreases in soil fertility with a radial direction from homesteads affect grain yield. More than $5 \mathrm{t} \cdot \mathrm{ha}^{-1}$ maize yield could be obtained by increasing manure and chemical fertilizer use near homesteads compared with $<1 \mathrm{t} \cdot \mathrm{ha}^{-1}$ in distant fields ${ }^{[31]}$. This indicates that there is room to increase crop productivity through manure and fertilizer use considering specific niches of soil fertility within heterogeneous farms ${ }^{[52]}$. In addition, crop production is an integrated system which needs all nutrient elements, suitable land preparation, soil and crop management, nutrient management, and irrigation, contributing simultaneously to high crop production. These elements will improve nutrient use by crops by modifying the environment of crop growth. In summary, replenishing soil fertility with manures and chemical fertilizers to transform soil fertility from a vicious to a beneficial cycle is the primary biophysical requirement for increasing grain yields from 1 to $5 \mathrm{t} \cdot \mathrm{ha}^{-1}$ in tropical Africa (Fig. 7).

\subsection{Lessons learned by Kenya from grain production at Quzhou County: avoiding excessive fertilizer inputs}

Fertilizer application is a double-edged sword in grain production. It provides nutrients to meet crop demand but it can result in a waste of resources and environmental degradation due to excessive nutrient supply (eutrophication). In the present study, $250 \mathrm{~kg} \cdot \mathrm{ha}^{-1} \mathrm{~N}$ and $60 \mathrm{~kg} \cdot \mathrm{ha}^{-1} \mathrm{P}$ accumulated in the major croplands over the past 20 years when grain yield increased to $>5 \mathrm{t} \cdot \mathrm{ha}^{-1}$ at Quzhou, indicating a large nutrient surplus in the major Quzhou arable lands (Fig. 2). This is a lesson for Kenya to learn from Quzhou grain production. On the North China Plain, average nutrient application rates exceed crop uptake, resulting in a large nutrient surplus ${ }^{[53]}$. It has been estimated that $>70 \%$ of the cropland suffers from excess synthetic N use on the North China Plain (receiving 2-3 times crop needs). On average, from 1980 to 2007, $242 \mathrm{~kg} \cdot \mathrm{ha}^{-1} \mathrm{P}$ accumulated in Chinese croplands, resulting soil Olsen-P increasing on average from 7.4 to $24.7 \mathrm{mg} \cdot \mathrm{kg}^{-1[54]}$.

Excessive fertilization can result in low resource use efficiency and high environmental risk for crop production $^{[55,56]}$. Compared with developed countries such as in the EU and the USA, $\mathrm{N}$ use efficiency in China has been very low $^{[54]}$. Partial factor productivity of $\mathrm{N}$ in maize cropping systems in China is $<20 \mathrm{~kg} \cdot \mathrm{kg}^{-1}$ while in the USA it is up to $50 \mathrm{~kg} \cdot \mathrm{kg}^{-1[55,56]}$. A large nutrient surplus has led to a series of environment impacts such as soil acidification ${ }^{[57]}$, air pollution and water eutrophication $^{[57-59]}$.

Chinese farmers are commonly misled by the assumption that high inputs mean high outputs, with increased nutrient concentrations in the soil solution from excessive application of fertilizers ${ }^{[60]}$. Misconceptions of farmers 
regarding fertilizer management and low chemical fertilizer prices can likely explain the nutrient accumulation at Quzhou. Since the 1960s, the Chinese government has released a series of subsidies to lower chemical fertilizer prices, giving farmers the capacity to purchase fertilizers $^{[57]}$. Currently, some Africa governments have realized that subsidies for fertilizers are a matter of life and death for African agriculture and have issued policies for subsidized fertilizers ${ }^{[61]}$. Use of chemical fertilizers by Malawian farmers increased by about $20 \%$ following the introduction of subsidies ${ }^{[61]}$. The lesson learned in Kenya should provide accurate information for farmers when they use chemical fertilizers.

\section{Conclusions}

The average grain yield in Quzhou increased from 1 to $3 \mathrm{t} \cdot \mathrm{ha}^{-1}$ with the application of manures and some chemical fertilizers after soil desalinization. The yield increased from 3 to $5 \mathrm{t} \cdot \mathrm{ha}^{-1}$ mostly by manipulating soil fertility with enhanced use of chemical fertilizers associated with policy support. Soil fertility was modified due to chemical fertilizer and manure use and high $\mathrm{C}$ deposition from increased plant growth. Hence, a selfreinforcing cycle between soil fertility and plant growth induced by nutrient inputs was established in Quzhou grain production. However, in Africa, grain yield has remained at around $1 \mathrm{t} \cdot \mathrm{ha}^{-1}$ due to low soil fertility induced by limited external nutrient use over a long period. This suggests that there is the potential to increase the grain yield from 1 to $5 \mathrm{t} \cdot \mathrm{ha}^{-1}$ in Kenya by increasing soil fertility with nutrient application, indicating that plentiful food production could be achieved by developing a selfreinforcing cycle between soil fertility and plant growth in Kenyan grain production.

Supplementary material The online version of this article at https://doi. org/10.15302/J-FASE-2020359 contains supplementary material (Fig. S1).

Acknowledgements This work was supported by the China Scholarship Council (201913043), the Bill \& Melinda Gates Foundation (OPP1209192), the "Sino-Africa Friendship" China government Scholarship (2019-1442), and the National Natural Science Foundation of China (31701999).

Compliance with ethics guidelines Xiaoqiang Jiao, Jianbo Shen, and Fusuo Zhang declare that they have no conflicts of interest or financial conflicts to disclose.

This article does not contain any studies with human or animal subjects performed by any of the authors.

\section{References}

1. Tilman D. Global environmental impacts of agricultural expansion: the need for sustainable and efficient practices. Proceedings of the National Academy of Sciences of the United States of America, 1999, 96(11): 5995-6000
2. Food and Agriculture Organization of the United Nations (FAO). FAOSTAT database: agriculture production. Rome: FAO, 2019

3. Godfray H C J, Beddington J R, Crute I R, Haddad L, Lawrence D, Muir J F, Pretty J, Robinson S, Thomas S M, Toulmin C. Food security: the challenge of feeding 9 billion people. Science, 2010, 327(5967): 812-818

4. Shen J B, Cui Z L, Miao Y X, Mi G H, Zhang H Y, Fan M S, Zhang C C, Jiang R F, Zhang W F, Li H G, Chen X P, Li X L, Zhang F S. Transforming agriculture in China: from solely high yield to both high yield and high resource use efficiency. Global Food Security, 2013, 2(1): 1-8

5. Pingali P L. Green revolution: impacts, limits, and the path ahead. Proceedings of the National Academy of Sciences of the United States of America, 2012, 109(31): 12302-12308

6. van Ittersum M K, van Bussel L G, Wolf J, Grassini P, van Wart J, Guilpart N, Claessens L, de Groot H, Wiebe K, Mason-D'Croz D, Yang H, Boogaard H, van Oort P A, van Loon M P, Saito K, Adimo O, Adjei-Nsiah S, Agali A, Bala A, Chikowo R, Kaizzi K, Kouressy M, Makoi J H, Ouattara K, Tesfaye K, Cassman K G. Can subSaharan Africa feed itself? Proceedings of the National Academy of Sciences of the United States of America, 2016, 113(52): 1496414969

7. International Fund of Agriculture Development (IFAD). The state of food insecurity in the world 2012: economic growth is necessary but not sufficient to accelerate reduction of hunger and malnutrition. Rome: IFAD, 2012

8. Zhang J. China's success in increasing per capita food production. Journal of Experimental Botany, 2011, 62(11): 3707-3711

9. Yang H S. Resource management, soil fertility and sustainable crop production: experiences of China. Agriculture, Ecosystems \& Environment, 2006, 116(1-2): 27-33

10. Zhang F S, Cui Z L, Chen X P, Ju X T, Shen J B, Chen Q, Liu X J, Zhang W F, Mi G H, Fan M S, Jiang R F. Integrated nutrient management for food security and environmental quality in China. Advances in Agronomy, 2012, 116: 1-40

11. Sánchez P A. Tripling crop yields in tropical Africa. Nature Geoscience, 2010, 3(5): 299-300

12. Conway G, Toenniessen G. Science for African food security. Science, 2003, 299(5610): 1187-1188

13. Sanchez P A. A smarter way to combat hunger. Nature, 2009, 458 (7235): 148

14. Seguel O, Baginsky C, Contreras A, Covarrubias J I, González C, Poblete L. Physical properties of a fine textured haplocambid after three years of organic matter amendments management. Journal of Soil Science and Plant Nutrition, 2013, 13(3): 690-705

15. Vanlauwe B, Wendt J, Giller K E, Corbeels M, Gerard B. Fertilizer use is not required as a fourth principle to define Conservation Agriculture. Field Crops Research, 2014, 169: 149

16. Stier A C, Samhouri J F, Novak M, Marshall K N, Ward E J, Holt R $\mathrm{D}$, Levin P S. Ecosystem context and historical contingency in apex predator recoveries. Science Advances, 2016, 2(5): e1501769

17. Vanlauwe B, Six J, Sanginga N, Adesina A A. Soil fertility decline at the base of rural poverty in sub-Saharan Africa. Nature Plants, 2015, 1(7): 15101

18. Bationo A, Fairhurst T, Giller K, Kelly V, Lunduka R, Mando A, Walregi L. Africa Soil Health Consortium: handbook for integrated 
soil fertility management. CABI-eBook, 2012. doi: 10.1079/ 9781780642857.0000

19. Tong C L, Hall C A S, Wang H Q. Land use change in rice, wheat and maize production in China (1961-1998). Agriculture, Ecosystems \& Environment, 2003, 95(2-3): 523-536

20. Onduru D D, De Jager A, Gachini G N. The hidden costs of soil mining to agricultural sustainability in developing countries: a case study of machakos district eastern Kenya. International Journal of Agricultural Sustainability, 2005, 3(3): 167-176

21. Chianu J N, Chianu J N, Mairura F. Mineral fertilizers in the farming systems of sub-Saharan Africa. A review. Agronomy for Sustainable Development, 2012, 32(2): 545-566

22. Bebe B O, Udo H M J, Thorpe W. Development of smallholder dairy systems in the Kenya highlands. Outlook on Agriculture, 2002, 31(2): 113-120

23. Zhang W, Cao G, Li X, Zhang H, Wang C, Liu Q, Chen X, Cui Z, Shen J, Jiang R, Mi G, Miao Y, Zhang F, Dou Z. Closing yield gaps in China by empowering smallholder farmers. Nature, 2016, 537 (7622): 671-674

24. Omotayo O E, Chukwuka K S. Soil fertility restoration techniques in sub-Saharan Africa using organic resources. African Journal of Agricultural Research, 2009, 4(3): 144-150

25. National Bureau of Statistics of China (NBSC). China Statistical Yearbook. Beijing: China Statistics Press, 2018 (in Chinese)

26. McKeague J A. Manual on soil sampling and methods of analysis. Ottawa: CRC Press, 1978

27. Bremner J M. Inorganic Forms of Nitrogen. In: C.A. Black C A, eds. Methods of soil analysis, Part 2. Agronomy Monograph. Madison: ASA and SSSA, 1965, 9: 1149-1178

28. Westerman R L. Soil testing and plant analysis, 3rd ed, American Society of Agronomy and Soil Science Society of America, Madison: Wisconsin, 1990

29. Potter P, Ramankutty N, Bennett E M, Donner S D. Characterizing the spatial patterns of global fertilizer application and manure production. Earth Interactions, 2010, 14(2): 1-22

30. Johnson J M F, Allmaras R R, Reicosky D C. Estimating source carbon from crop residues, roots and rhizodeposits using the national grain-yield database. Agronomy Journal, 2006, 98(3): 622636

31. Tittonell P, Vanlauwe B, De Ridder N, Giller K E. Heterogeneity of crop productivity and resource use efficiency within smallholder Kenyan farms: Soil fertility gradients or management intensity gradients? Agricultural Systems, 2007, 94(2): 376-390

32. Fan M, Shen J, Yuan L, Jiang R, Chen X, Davies W J, Zhang F. Improving crop productivity and resource use efficiency to ensure food security and environmental quality in China. Journal of Experimental Botany, 2012, 63(1): 13-24

33. Jiang H, Han X Z, Zou W X, Hao X X, Zhang B. Seasonal and longterm changes in soil physical properties and organic carbon fractions as affected by manure application rates in the Mollisol region of Northeast China. Agriculture, Ecosystems \& Environment, 2018, 268: 133-143

34. Lassaletta L, Billen G, Grizzetti B, Anglade J, Garnier J A. 50 year trends in nitrogen use efficiency of world cropping systems: the relationship between yield and nitrogen input to cropland. Environmental Research Letters, 2014, 9(10): 105011
35. Jiao X, Lyu Y, Wu X, Li H, Cheng L, Zhang C, Yuan L, Jiang R, Jiang B, Rengel Z, Zhang F, Davies W J, Shen J. Grain production versus resource and environmental costs: towards increasing sustainability of nutrient use in China. Journal of Experimental Botany, 2016, 67(17): 4935-4949

36. Xu Z, Yu Z, Zhao J. Theory and application for the promotion of wheat production in China: past, present and future. Journal of the Science of Food and Agriculture, 2013, 93(10): 2339-2350

37. Erisman J W, Sutton M A, Galloway J, Klimont Z, Winiwarter W. How a century of ammonia synthesis changed the world. Nature Geoscience, 2008, 1(10): 636-639

38. Huang Y, Sun W J. Changes in topsoil organic carbon of croplands in mainland China over the last two decades. Chinese Science Bulletin, 2006, 51(15): 1785-1803

39. Xie Z B, Zhu J G, Liu G Q, Cadisch G, Hasegawa T, Chen C M, Sun H F, Tang Y, Zeng Q. Soil organic carbon stocks in China and changes from 1980s to 2000s. Global Change Biology, 2007, 13(9): 1989-2007

40. Barrett C B, Bevis L E. The self-reinforcing feedback between low soil fertility and chronic poverty. Nature Geoscience, 2015, 8(12): 907-912

41. Sanchez P A. Soil fertility and hunger in Africa. Science, 2002, 295 (5562): 2019-2020

42. Sanchez P A, Swaminathan M S. Cutting world hunger in half. Science, 2005, 307(5708): 357-359

43. Messina J P, Peter B G, Snapp S S. Re-evaluating the Malawian Farm Input Subsidy Programme. Nature Plants, 2017, 3(4): 17013

44. Vanlauwe B, Aihou K, Aman S, Iwuafor E N, Tossah B K, Diels J, Sanginga N, Lyasse O, Merckx R, Deckers J. Maize yield as affected by organic inputs and urea in the West African moist savanna. Agronomy Journal, 2001, 93(6): 1191-1199

45. Omotayo O E, Chukwuka K S. Soil fertility restoration techniques in sub-Saharan Africa using organic resources. African Journal of Agricultural Research, 2009, 4(3): 144-150

46. Tittonell P, Corbeels M, Van Wijk M T, Vanlauwe B, Giller K E. Combining organic and mineral fertilizers for integrated soil fertility management in smallholder farming systems of Kenya: explorations using the crop-soil model FIELD. Agronomy Journal, 2008a, 100 (5): $1511-1526$

47. Ajayi O C. User acceptability of sustainable soil fertility technologies: lessons from farmers' knowledge, attitude and practice in southern Africa. Journal of Sustainable Agriculture, 2007, 30(3): 21-40

48. Vanlauwe B, Giller K E. Popular myths around soil fertility management in sub-Saharan Africa. Agriculture, Ecosystems \& Environment, 2006, 116(1-2): 34-46

49. Karlberg L, Hoff H, Flores-López F, Goetz A, Matuschke I. Tackling biomass scarcity-from vicious to virtuous cycles in subSaharan Africa. Current Opinion in Environmental Sustainability, 2015, 15: 1-8

50. Folberth C, Yang H, Gaiser T, Abbaspour K C, Schulin R. Modeling maize yield responses to improvement in nutrient, water and cultivar inputs in sub-Saharan Africa. Agricultural Systems, 2013, 119: 2234

51. Henao J, Baanante C.Estimating rates of nutrient depletion in soils of agricultural lands of Africa. Available at International Fertilizer 
Development Center (IFDC) website on October 3, 2019

52. Tittonell P, Vanlauwe B, Corbeels M, Giller K E. Yield gaps, nutrient use efficiencies and response to fertilisers by maize across heterogeneous smallholder farms of western Kenya. Plant and Soil, 2008, 313(1-2): 19-37

53. Vitousek P M, Naylor R, Crews T, David M B, Drinkwater L E, Holland E, Johnes P J, Katzenberger J, Martinelli L A, Matson P A, Nziguheba G, Ojima D, Palm C A, Robertson G P, Sanchez P A, Townsend A R, Zhang F S. Nutrient imbalances in agricultural development. Science, 2009, 324(5934): 1519-1520

54. Li H G, Huang G Q, Meng Q F, Ma L, Yuan L X, Wang F H, Cui Z L, Shen J B, Chen X P, Jiang R F, Zhang F S. Integrated soil and plant phosphorus management for crop and environment in China: a review. Plant and Soil, 2011, 349(1-2): 157-167

55. Li H, Liu J, Li G, Shen J, Bergström L, Zhang F. Past, present, and future use of phosphorus in Chinese agriculture and its influence on phosphorus losses. Ambio, 2015, 44(S2): S274-S285

56. Zhang F S, Cui Z L, Zhang W F. Managing nutrient for both food security and environmental sustainability in China: an experiment for the world. Frontiers of Agricultural Science and Engineering,
2014, 1(1): 53-61

57. Norse D, Ju X T. Environmental costs of China's food security. Agriculture, Ecosystems \& Environment, 2015, 209: 5-14

58. Guo J H, Liu X J, Zhang Y, Shen J L, Han W X, Zhang W F, Christie P, Goulding K W, Vitousek P M, Zhang F S. Significant acidification in major Chinese croplands. Science, 2010, 327(5968): $1008-1010$

59. Liu X, Vitousek P, Chang Y, Zhang W, Matson P, Zhang F. Evidence for a historic change occurring in China. Environmental Science \& Technology, 2016, 50(2): 505-506

60. Chen X P, Cui Z L, Vitousek P M, Cassman K G, Matson P A, Bai J S, Meng Q F, Hou P, Yue S C, Römheld V, Zhang F S. Integrated soil-crop system management for food security. Proceedings of the National Academy of Sciences of the United States of America, 2011, 108(16): 6399-6404

61. Denning G, Kabambe P, Sanchez P, Malik A, Flor R, Harawa R, Nkhoma P, Zamba C, Banda C, Magombo C, Keating M, Wangila J, Sachs J. Input subsidies to improve smallholder maize productivity in Malawi: toward an african green revolution. PLoS Biology, 2009, 7(1): e1000023 